\title{
Watermarking Video Menggunakan Metode Transformasi Wavelet Diskrit
}

\author{
Syamsuryadi $^{1)}$, Ibnu Aqii ${ }^{2)}$ \\ ${ }^{1)}$ Program Studi Informatika, Universitas Sriwijaya \\ ${ }^{2)}$ Program Studi Manajemen Informatika, AMIK Bina Sriwijaya \\ ${ }^{1)}$ Jln. Srijaya Negara Bukit Besar Palembang 30139 \\ ${ }^{2)} J l n$. HM. Ryacudu No. 248 Ulu Palembang Kode Pos 30252 \\ E-mail :syamsuryadi@unsri.ac.id $)^{1}$, ibnu160672@gmail.com ${ }^{2)}$
}

\begin{abstract}
Watermarking videos are useful to determine authentication rights to a video. The step of watermarking is by inserting binary images on an MPEG1 format video using discrete wavelet transformations, and extracting watermark videos. Analysis of video watermark quality can be known by calculatong PSNR. Video watermark quality analysis is done after carrying out the watermarking and extraction process to find out the difference the original video quality and the video watermark and the insertion image used. The results of video watermark quality analysis showed that $100 \%$ video watermarks did not change from the original video and binary imagery was better than the color image in the insert image.
\end{abstract}

Keyword : video watermarking, authentication, binary imagery, insert image, discrete wavelet transformation, PSNR.

\begin{abstract}
Abstrak
Watermarking video berguna untuk menentukan hak otentikasi terhadap suatu video. Tahapan watermarking adalah penyisipan citra biner terhadap suatu video berformat MPEG1 menggunakan transformasi wavelet diskrit, dan melakukan ekstraksi terhadap video watermark. Analisis kualitas video watermark dapat diketahui dengan perhitungan PSNR. Analisis kualitas video watermark dilakukan setelah melakukan proses watermarking dan ekstraksi untuk mengetahui apakah perbedaan kualitas video asli dengan video watermark dan citra sisipan yang digunakan. Hasil analisis kualitas video watermark menunjukkan bahwa 100\% video watermark tidak mengalami perubahan dari video asli dan citra biner lebih baik daripada citra berwarna pada citra sisipan.
\end{abstract}

Kata kunci : watermarkingi video, otentikasi, citra biner, citra sisipan, transformasi wavelet diskrit, PSNR. 


\section{Pendahuluan}

Watermarking sangat diperlukan untuk membantu dalam menentukan hak otentikasi terhadap suatu karya. Selain itu, untuk menghindari kejahatan komputer (cybercrime) dalam pelanggaran hak cipta dan pengakuan kepemilikan data atau sebuah karya seperti pada gambar, suara dan video. Oleh karena itu watermarking sangat penting untuk membantu dalam penegasan kepemilikan video. Watermarking video menggunakan citra berupa tanda tangan sebagai citra sisipan yang digunakan sebagai data otentikasi dari video. Setiap organisasi ataupun perorangan menggunakan watermarking sebagai identitas dari sebuah karya.

Watermarking merupakan suatu cara untuk menyembunyikan atau menanamkan data atau informasi tertentu dalam suatu data digital lainnya dan mampu menghadapi proses-proses pengolahan sinyal digital sampai pada tahap tertentu. Watermarking merupakan proses penyisipan sinyal atau data dalam suatu media, sedangkan watermark video merupakan video yang telah mengandung informasi. Teknologi watermarking dapat dilakukan pada berbagai jenis pengolahan atau proses, yaitu teks, citra, video, dan audio.

\section{A. Watermarking}

Watermarking merupakan suatu bentuk dari steganography dalam mempelajari bagaimana teknik penyimpanan suatu data (digital) dalam data host digital yang lain (Istilah host digunakan untuk data atau sinyal digital yang ditumpangi). ${ }^{[1]}$

Sebagian besar aplikasi watermarking mengharuskan algoritma watermarking digital untuk menanamkan watermark sedemikian sehingga tidak mempengaruhi kualitas media yang disisipi watermark. Media yang telah disisipi watermark haruslah sulit dibedakan dengan media aslinya oleh indera manusia.

Proses penanaman watermarking haruslah aman, sehingga pihak yang tidak berhak harus tidak dapat mendeteksi keberadaan data yang ditanamkan, dan tidak mampu menghilangkan data tersebut. ${ }^{[2]}$

\section{B. Video Format MPEG1}

MPEG1 adalah video yang memiliki resolusi kecil dengan ukuran frame $352 \times 240$ piksel dengan 30 frame/detik (fps) atau $325 \times 288$ piksel dengan 25 fps. Namun standar ini juga mampu menampilkan resolusi sampai tingkat 4095x4095 dengan 60 frame/detik. Dengan kecepatan transfer 1,5 Mb/detik, dan bisa lebih tinggi sesuai keperluan. Dalam format MPEG1 terdapat group of picture, yang terdiri dari empat jenis frame yaitu frame $\mathrm{I}$, frame $\mathrm{P}$, frame $\mathrm{B}$ dan frame $\mathrm{D}$. Untuk proses penyisipan disisipkan pada frame I atau frame P. ${ }^{[3]}$

\section{Video Watermarking}

Video merupakan susunan dari beberapa frame. Penyisipan watermark video data tidak terlihat oleh mata biasa dan sulit untuk dihilangkan tanpa mengurangi kualitas dari video. Semakin banyak data pesan yang disembunyikan, maka perubahan pada video menjadi semakin mudah terlihat.

Keuntungan dari video watermarking adalah banyaknya data yang dapat disembunyikan di dalamnya, serta fakta bahwa video merupakan "streams" dari gambar-gambar menyebabkan adanya distorsi pada salah satu frame gambar tidak akan terlihat dengan mudah melalui mata manusia.

\section{Transformasi Wavelet Diskrit}

Proses transformasi wavelet ini pertama kali dapat diwakili dengan proses melewatkan sinyal asli ke dalam low pass filter (LPF) dan high pass filter (HPF). ${ }^{[4]}$ Setelah itu, nilai skala dari wavelet dapat diubah dengan menggunakan proses upsampling dan down sampling.

Video asli dimasukkan dalam perangkat lunak yang telah dibuat bersamaan dengan citra sisipan yang digunakan sebagai media watermark. Pada proses watermarking digunakan metode transformasi wavelet diskrit, yang didalamnya terdapat transformasi wavelet diskrit maju dan transformasi diskrit balik. Pada proses transformasi diskrit maju dilakukan proses dekomposisi, yaitu menguraikan sinyal asli ke dalam komponen-komponen aslinya. Karena bersifat multiresolusi, maka model wavelet dapat dengan mudah digeneralisasi ke ukuran dimensi lain dimana $n>0$. Pada umumnya, suatu sinyal seperti suara ditransformasikan dengan transformasi diskrit satu dimensi, sedangkan pengolahan citra dua dimensi, menurut model wavelet juga diturunkan dalam bentuk dua dimensi, sehingga dapat diimplementasikan untuk memproses citra digital. Setelah di lakukan transformasi wavelet maju dua dimensi skala dua, maka di dekomposisi menjadi empat subband sesuai frekuensinya yaitu LL (low, low), LH (low, high), HL (high, low), HH (high, high) dengan menggunakan transformasi wavelet dengan filter HAAR. Pada transformasi wavelet diskrit balik dilakukan proses rekonstruksi, yaitu proses mengembalikan kembali komponen-komponen frekuensi menjadi sinyal semula.

\section{E. Dekomposisi}

Proses dekomposisi dilakukan untuk menguraikan sinyal asli ke dalam komponen-komponen aslinya. Jika citra asli didekomposisi menjadi empat subband sesuai frekuensinya, yakni $\mathrm{L}_{\mathrm{L}}, \mathrm{L}_{\mathrm{H}}, \mathrm{H}_{\mathrm{L}}, \mathrm{H}_{\mathrm{H}}$ dengan transformasi wavelet dan filter HAAR, secara matematis dihasilkan dengan menggunakan matriks sebagai berikut ${ }^{[5]}$ : 
Matrik
$\mathrm{L}=1 / 2\left[\begin{array}{cccccccc}1 & 1 & 0 & 0 & 0 & 0 & \ldots & 0 \\ 0 & 1 & 1 & 0 & 0 & 0 & \ldots & 0 \\ 0 & 0 & 1 & 1 & 0 & 0 & \ldots & 0 \\ 0 & 0 & 0 & 1 & 1 & 0 & \ldots & 0 \\ 0 & 0 & 0 & 0 & 1 & 1 & \ldots & 0 \\ 0 & 0 & 0 & 0 & 0 & \ldots & \ldots & 0 \\ \ldots & \ldots & \ldots & \ldots & \ldots & \ldots & 1 & 1 \\ 0 & 0 & 0 & 0 & 0 & 0 & 0 & 1\end{array}\right]$

Matriks High Pass HAAR (H) :

$$
\mathrm{H}=1 / 2\left[\begin{array}{cccccccc}
1 & -1 & 0 & 0 & 0 & 0 & \ldots & 0 \\
0 & 1 & -1 & 0 & 0 & 0 & \ldots & 0 \\
0 & 0 & 1 & -1 & 0 & 0 & \ldots & 0 \\
0 & 0 & 0 & 1 & -1 & 0 & \ldots & 0 \\
0 & 0 & 0 & 0 & 1 & -1 & \ldots & 0 \\
0 & 0 & 0 & 0 & 0 & \ldots & \ldots & 0 \\
\ldots & \ldots & \ldots & \ldots & \ldots & \ldots & 1 & -1 \\
0 & 0 & 0 & 0 & 0 & 0 & 0 & 1
\end{array}\right]
$$

Matr

iks Low Pass dan High Pass HAAR (y):

$$
\mathrm{y}=1 / 2\left[\begin{array}{cccccccc}
1 & 1 & 0 & 0 & 0 & 0 & \ldots & 0 \\
0 & 1 & 1 & 0 & 0 & 0 & \ldots & 0 \\
0 & 0 & 1 & 1 & 0 & 0 & \ldots & 0 \\
0 & 0 & 0 & 1 & 1 & 0 & \ldots & 0 \\
0 & 0 & 0 & 0 & 1 & 1 & \ldots & 0 \\
1 & -1 & 0 & 0 & 0 & 0 & \ldots & 0 \\
0 & 1 & -1 & 0 & 0 & 0 & \ldots & 0 \\
0 & 0 & 1 & -1 & 0 & 0 & \ldots & 0 \\
0 & 0 & 0 & 1 & -1 & 0 & \ldots & 0 \\
0 & 0 & 0 & 0 & 1 & -1 & \ldots & 0
\end{array}\right]
$$

\section{F. Rekonstruksi}

Proses rekonstruksi adalah proses mengembalikan komponen frekuensi menjadi sinyal semula melalui proses upsampling dan pemfilteran dengan koefisienkoefisien filter balik.

\section{G. Penerapan Sistem}

1. Penyisipan

Proses penyisipan watermarking video, pertama kali host video disegmentasikan ke dalam sequence video, seringkali dipilih secara acak untuk penyisipan watermark. Teknik penyisipan menggunakan metode transformasi wavelet diskrit yang dilakukan pada salah satu frame video dan citra sisipan. Langkah awal dari penyisipan ini adalah mengetahui nilai frame video dan nilai dari citra sisipan. Nilai dari frame video tersebut berupa matriks, selanjutnya nilai dari frame video ditransformasikan menggunakan metode transformasi wavelet diskrit maju, pada bagian ini dilakukan proses dekomposisi. Proses dekomposisi data dimulai dengan melakukan dekomposisi baris dari data video yang diikuti dengan dekomposisi kolom pada koefisien data keluaran pertama. Setelah di filterisasi menggunakan DWT HAAR, maka akan menghasilkan empat subband, yaitu LL, LH, HL, HH. Pada proses penyisipan menggunakan frame yang mengandung subband LL. Hasil nilai transformasi dari frame video dan citra sisipan tersebut akan dikombinasikan dengan operasi XOR. Pada saat inilah watermark ditanamkan ke dalam frame video host. Setelah didapat nilai dari operasi XOR, maka dilanjutkan dengan permutasi menggunakan metode transformasi wavelet diskrit balik untuk membentuk kembali nilai frame video host. Pada tahap ini dilakukan proses rekonstruksi dan dilanjutkan dengan proses pemfilteran. Semua tahapan proses tersebut dilakukan untuk penyisipan citra sisipan pada video host.

Digram alir proses penyisipan citra ke dalam video host ditujukkan pada Gambar 1.

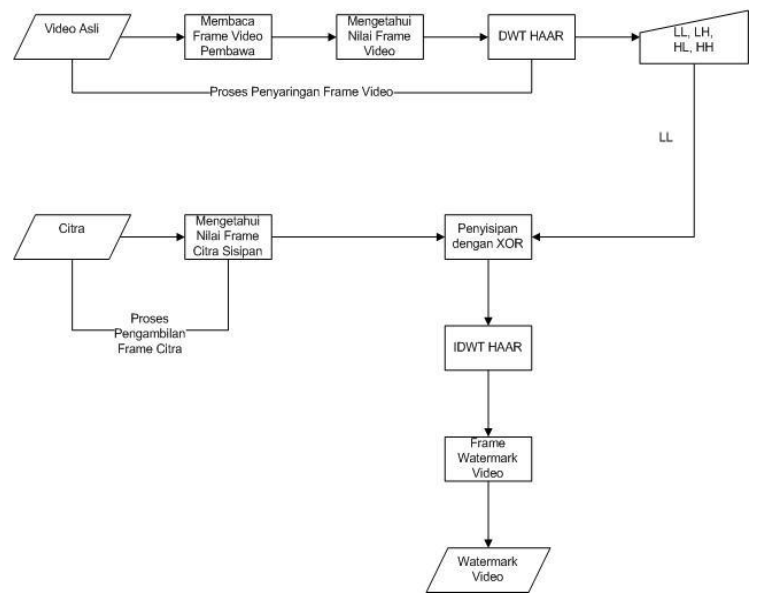

Gambar 1. Proses Penyisipan dengan Metode XOR

2. Ekstraksi

Proses ekstraksi adalah proses pengambilan citra sisipan dan memisahkannya dari video pembawa.

Langkah-langkah yang dilakukan dalam proses ekstraksi yaitu, membaca frame video yang telah di watermark dan mengetahui nilai dari frame video tersebut. Kemudian nilai matriks dari frame tersebut difilterisasi menggunakan DWT HAAR, sehingga menghasilkan 4 subband sinyal. Subband adalah kumpulan koefisien transformasi yang dihasilkan dari proses filterisasi oleh highpass filter dan lowpass filter secara berurutan. Dalam proses highpass filter dan lowpass filter membutuhkan matriks dekomposisi baris dan dekomposisi kolom untuk mendapatkan kembali 
nilai dari frame video, begitu pula untuk mendapatkan nilai dari citra sisipan. Adapun subband yang dihasilkan tersebut adalah LL, LH, HL, HH. Dalam proses ini dilakukan pemilihan subband yang akan digunakan sebagai tempat penyembunyian informasi. Dipilih subband LL yang kemudian nilai-nilai frame pada subband LL dikurangi dengan nilai-nilai frame pada citra sisipan yang nilainya telah dinormalisasi dengan nilai XOR yang dimasukkan user di awal pada proses penyisipan (embedding). selanjutnya proses pengembalian nilai frame menggunakan metode invers DWT.

Digram alir proses ekstraksi citra pada video ditunjukkan Gambar 2.

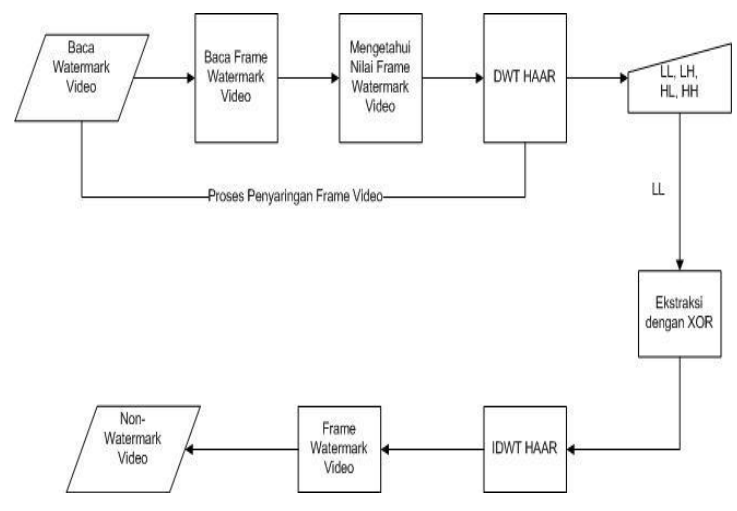

Gambar 2. Proses Ekstraksi

3. Kualitas Video

Penghitungan kualitas video dapat dilakukan dengan menghitung peak signal noise ratio (PSNR) sebagai pembanding kualitas video hasil rekonstruksi dengan video asal. PSNR didefinisikan melalui signal noise ratio (SNR). SNR digunakan untuk mengukur tingkat kualitas sinyal. Nilai ini dihitung berdasarkan perbandingan antara sinyal dengan nilai derau. Kualitas sinyal berbanding lurus dengan nilai SNR. Semakin besar nilai SNR semakin baik kualitas sinyal yang dihasilkan. Nilai PSNR berkisar antara 20 dan 40. ${ }^{[6]}$

Pertama yang dilakukan adalah menghitung nilai mean squared error (MSE) dari hasil rekonstruksi. Root mean squarred error (RMSE) adalah akar dari MSE. ${ }^{[6]}$

$$
M S E=\frac{\sum[f(i, j)-F(i, j)]^{2}}{N^{2}}
$$

$\mathrm{N}^{2}=$ Hasil perkalian panjang dan lebar frame dalam piksel.

$\mathrm{F}(\mathrm{i}, \mathrm{j})=$ Frame hasil rekonstruksi.

$\mathrm{f}(\mathrm{i}, \mathrm{j})=$ Frame asal.

Berdasarkan persamaan MSE, maka nilai PSNR dapat dihtung dengan persamaan (2). Nilai PSNR direpresentasikan dalam skala desibel $(\mathrm{dB}) .{ }^{[6]}$

$$
P S N R=20 \log _{10}\left(\frac{255}{R M S E}\right)
$$

Nilai 255 dalam persamaan (2) merupakan batas atas dari sebuah piksel.

\section{Pembahasan}

Pengujian dilakukan dalam 2 percobaan, percobaan pertama dilakukan dengan penyisipan citra dengan citra biner tanda tangan dengan ukuran 40x40 dan format jpg. Percobaan kedua dilakukan dengan citra biner universitas sriwijaya dengan format jpg dan citra berwarna universitas sriwijaya dengan format jpg.

\section{A. Percobaan 1}

Percobaan I ekstraksi dengan video MPEG1 dan citra sisipan tanda tangan hitam putih diperlihatkan pada Tabel 1.

Tabel 1. Percobaan 1

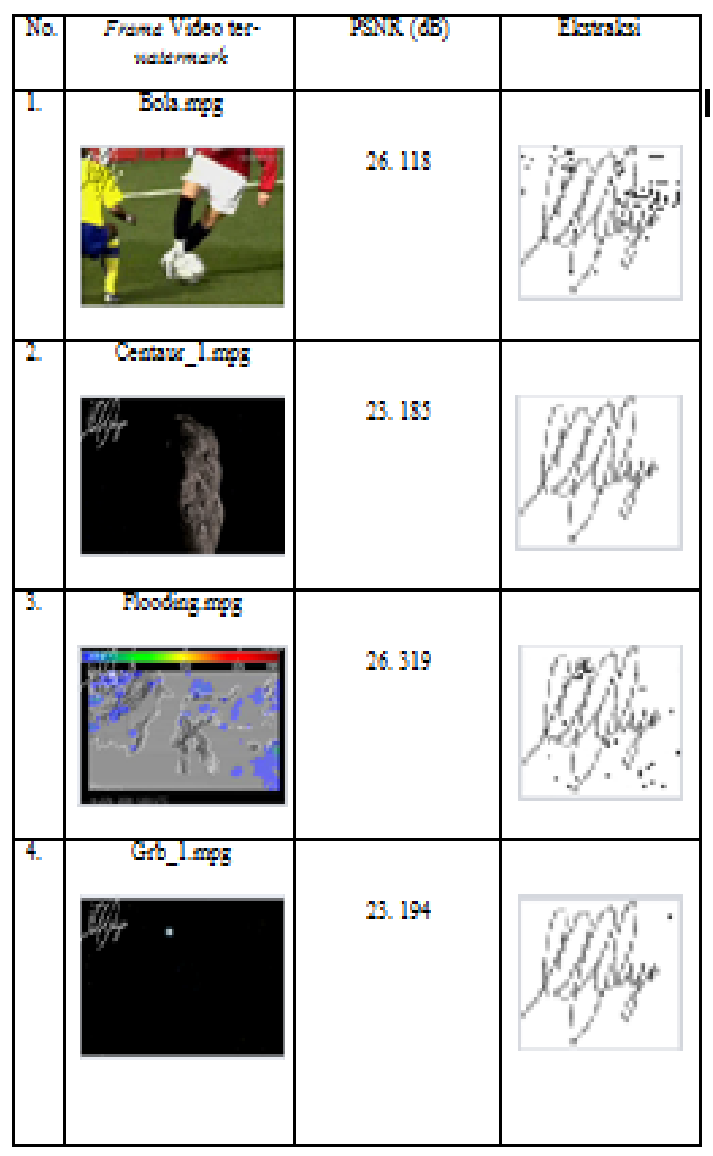

B. Percobaan 2

Percobaan 2 ekstraksi dengan video MPEG 1 dan citra sisipan yang berbeda. 
Tabel 2. Percobaan 2

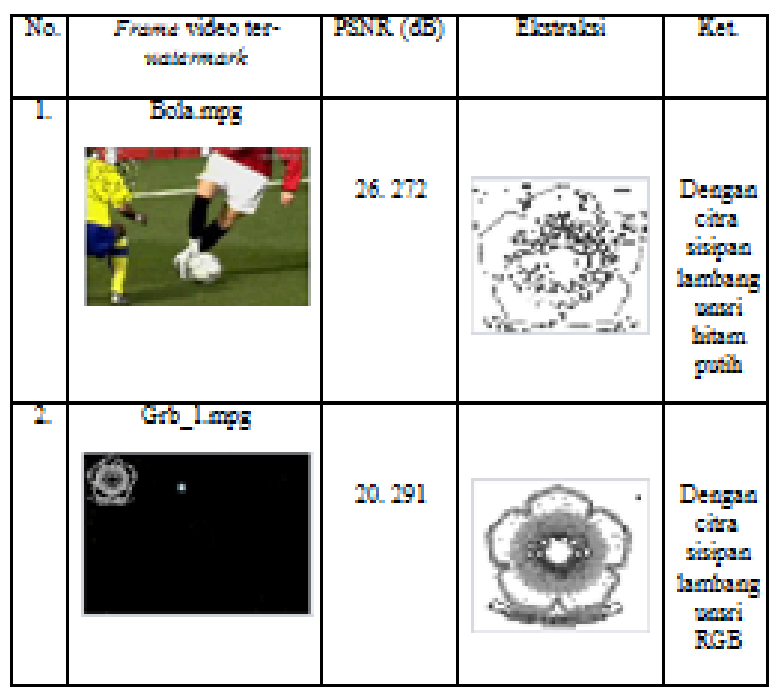

\section{Hasil}

Percobaan 1 hasilnya dapat dilihat pada Tabel 1. Sepuluh objek video dengan format MPEG1 mempunyai ekstraksi watermark dengan nilai PSNR yang berbeda, pada percobaan ini dengan menyisipkan citra watermark berupa tanda tangan hitam putih rata-rata untuk 10 objek video memiliki hasil Peak Signal to Noise Ratio (PSNR) yaitu minimal $23.1851900 \mathrm{~dB}$ pada video centaur_1.mpg, pada video hst_2.mpg memiliki nilai PSNR maksimal, yaitu $29.7273155 \mathrm{~dB}$. Semakin tinggi nilai PSNR artinya semakin identik citra tersebut terhadap citra aslinya.

Sedangkan untuk percobaan 2 yaitu dilakukan dengan video format MPEG1 dan dengan citra sisipan yang berbeda, yaitu citra lambang unsri hitam putih dan lambang unsri RGB. Hasilnya dapat pada Tabel 2 bahwa menggunakan citra sisipan unsri dengan warna hitam putih memiliki nilai PSNR $26.2727956 \mathrm{~dB}$, sedangkan citra sisipan lambang unsri RGB memiliki nilai PSNR yang lebih kecil, yaitu $20.2917171 \mathrm{~dB}$.

Hasil percobaan didapatkan disimpulkan bahwa proses watermark pada video menggunakan metode transformasi wavelet diskrit memiliki hasil yang cukup baik, karena citra sisipan yang ada di dalam video tidak terlihat secara kasat mata namun setelah diekstraksi citra sisipan tetap dapat dikenali dan nilai PSNR pun cukup baik, dengan nilai maksimal hampir mencapai $30 \mathrm{~dB}$.

\section{Kesimpulan}

Perangkat lunak yang dikembangkan dapat melakukan proses watermarking pada video. Citra sisipan yang dipilih berupa citra berwarna hitam putih berupa tanda tangan dengan ukuran 40x40. Berdasarkan hasil pengujian ditarik kesimpulan bahwa:

a. Citra biner tanda tangan memiliki hasil terbaik untuk digunakan sebagai citra sisipan, dibandingkan dengan citra biner logo unsri dan citra berwarna logo unsri. b. Perbandingan yang ditinjau dari perhitungan Peak Signal to Noise Ratio (PSNR) menunjukan bahwa antara video original dan video hasil watermark hampir sama sehingga secara kasat mata tidak dapat membedakan kedua video.

\section{Daftar Pustaka}

Alfatwa, Dean Fhatony. 2007. watermarking pada citra digital menggunakan discrete wavelet transform. Institute Teknologi Bandung, Bandung

Gandhe, S, T,. Ujwa Potdar., K T Talele. (2009). Dual Watermarking in Video Using Discrete Wavelet Transform (Second International Conference on Machine Vision), India

Merchant, S. N., Harchandi A S. (2003). Watermarking of Video Data Using Integer to Integer Discrete Wavelet Transform. IEEE, Mumbai.

Priyoyudo, Ady., Aris Sugiharto., Indriyati. (2006). Teknik Pembuktian Kepemilikan Citra Digital Dengan Watermarking Pada Domain Wavelet. Universitas Diponegoro, Semarang.

Putra, Darma., (Ed). (2010). Pengolahan Citra Digital. Penerbit Andi, Yogyakarta.

Ting-Sun, Ming., Supavadee Aramvith. (1999). MPEG 1 and MPEG2 standards. University of Washington, Washington. 